University for Business and Technology in Kosovo

UBT Knowledge Center

UBT International Conference

2014 UBT International Conference

Nov 7th, 3:00 PM - 3:15 PM

\title{
The impact of occupational stressors in public administration: What should employees do?
}

\author{
Edit Lezha \\ University of Shkoder, editlezha@gmail.com \\ Gezim Dibra \\ University of Shkoder, gdsh53@yahoo.com \\ Jozef Bushati \\ University of Shkoder, jozefbushati@gmail.com \\ Bujane Topalli \\ University of Shkoder, bujane.topalli@yahoo.com
}

Follow this and additional works at: https://knowledgecenter.ubt-uni.net/conference

Part of the Business Commons

\section{Recommended Citation}

Lezha, Edit; Dibra, Gezim; Bushati, Jozef; and Topalli, Bujane, "The impact of occupational stressors in public administration: What should employees do?" (2014). UBT International Conference. 36.

https://knowledgecenter.ubt-uni.net/conference/2014/all-events/36

This Event is brought to you for free and open access by the Publication and Journals at UBT Knowledge Center. It has been accepted for inclusion in UBT International Conference by an authorized administrator of UBT Knowledge Center. For more information, please contact knowledge.center@ubt-uni.net. 


\title{
The impact of occupational stressors in public administration: What should employees do?
}

\author{
Edit Lezha ${ }^{1}$, Gezim Dibra ${ }^{2}$, Jozef Bushati ${ }^{3}$, Bujane Topalli ${ }^{4}$ \\ ${ }^{1234} \mathrm{Faculty}$ of Educational Sciences, \\ ${ }^{1234}$ University of Shkoder "Luigj Gurakuqi”. Shkoder, Albania. \\ editlezha@gmail.com,gdsh53@yahoo.com,jozefbushati@gmail.com, bujane.topalli@yahoo.com
}

\begin{abstract}
Frequent and rapid changes are influencing factors in the quality of human life. Work intensity, the difference between material and spiritual needs of employees and their needs balance, are more general factors that cause stress at work. These requirements may be perceived as positive or negative challenges. Requirements imbalances can lead in procrastination which increase work related stress and concern in managing it. So stress is a consequence of the interaction of employees with conditions that surround them, but, on the other hand employee themselves can affect their own level of stress that they are experiencing in workplace. Organizations that make work-life balance possible are more likely to retain the employees in whom they have already invested and avoid the significant costs associated with replacing them. Also, this research aimed to explore how employees perceived occupational stress and what kind of strategies they used in order to minimize occupational stressors in workplace.
\end{abstract}

Keywords: occupational stressors, public administration, employee

\section{Introduction}

Stress is one of the most discussed phenomena nowadays. Frequent and rapid changes are contributing factor to the quality of human and organizational life. Intensity at work, the difference between spirit and material needs of employees fare, with the balance there are more general factors that cause stress at work. Studies have shown that employee himself is one of the main causes of stress. "Stress is completely the opposite of efficiency. Long-term stress reduces the employee capacity to solve problems, which leads to increased risk of infection from diseases and absence from work for health reasons "[5]

Selye (1974) noted that such requests constitute what is called 'stress at work'. Such requests may be perceived positively as challenges, changes and so forth by individuals, depending on their abilities to handle them. Anything that goes beyond the individual level of tolerance regarding these requirements or conditions in the workplace will be perceived in a negative way and will have adverse effects relevant, such as tension, anxiety, frustration, illness etc. (Numerof, RE; 1987). French, Cobb, Caplan, and Van Harrison Pinneau (1976) explained that stress at work refers to "every feature in the work environment which poses a threat to the individual or excess demand or insufficient funds to meet its needs".

In this study, stress at work is determined based on an interactive model of stress. So stress at work is the interaction of working conditions with employees' characteristics, which exceed the job requirements of employees' skills for dealing with them (Ross and Altmaier, 1994)

While Otto (1986) emphasizes that a balance between demands and resources, helps individuals to function comfortably and stress occurs when there is an indication of misfit between these two elements. According to Levi (1979), job stress begins when there is a discrepancy between professional demands and opportunities on the one hand and employee capacity, the needs and expectations of its turn.

\subsection{Stressors at work}

According to Robert A. Baron [6], stress is multi-dimensional process that occurs in response to events or situations in our environment, which is called the stressor [6]. Therefore, a stressor stimulus is considered when an individual cannot face a certain situation. Baron [6] noted that an interesting feature in the study 
of stress is that people perceive stressors differently. A situation can be a stressor for one person but not for another. This is according to Lazarus [4] depends on how individuals perceive the situation that they face. National Institute for Occupational Safety and Health has identified the following categories of stressors that represent the main sources of stressors for employees. They are $\mathrm{n} s$ work overload, the rapid pace of work, hours of solid or inconvenient, conflicting or ambiguous roles, concerns about career security, poor interpersonal relationships in the workplace, and unpleasant working conditions. Similarly, Cooper (1986) identified five major sources of job stress. They are the working conditions (poor condition to work, work overload, time pressure and responsibility for things or others), role in the organization (ambiguity role and role conflict), career development (increase in duty, reduction in task, lack of job security, ambitions, etc.), relationships at work (poor relationship with the boss, subordinates or colleagues, difficulty in delegating responsibilities, etc.), organizational structure and climate (little or no participation in decision-making, restriction behavioral, department policies, lack of effective counseling, etc.).

\section{Methodology}

Scientific tasks of this study are based on three main areas:

a) The present theoretical experience stress at work.

b) To analyze which factors they are more influential stress at work.

c) To make recommendations for managing stress at work.

\subsection{Objectives of the study are:}

- To determine the level of stress experienced by employees working in Public Administrations.

- To determine more influential factors (stressors) which cause stress to employees.

\subsection{Hypothesis:}

H1: Among stress level and work stressors (work overload, career development, timelines, work under load, interpersonal relationships and conflict of roles.) there's a significant positive correlation

\subsection{Sample}

The participants of this study are employees of public administration at Municipality of Shkoder. The study included 106 participants, who 57 participants are female and 49 are male. A survey research design was used in this study to investigate relations among variables. The sampling method used in this research was Cluster sampling which is commonly implemented as multistage sampling. This is a complex form of cluster sampling in which two or more levels of units are embedded one in the other. ). In following stages, in each of those selected clusters, additional samples of units are selected, and so on. All ultimate units (individuals, for instance) selected at the last step of this procedure are then 
surveyed. This technique, thus, is essentially the process of taking random subsamples of preceding random samples.

\subsection{Measuring Instruments}

The first survey was used to measure the stress levels of employees. This survey was adapted from Mc Lean [2] and is standardizing. The total number of cases where the respondent is 19 must choose between 19 alternatives divided into 3 intervals.

The maximum total score is 57 for 19 issues point. Average score is 38 points. If the subject gets 38 and above is classified as a person who experiences high stress at work. If respondent gets below 38 points, then the entity is classified as a person experiencing low stress in the work place.

The second survey was adapted from Tsan (1998) and is standardized. This instrument measures the six stressors in the work environment as; overload at work, career development, and timelines, work under load, interpersonal relations and role conflict issues. The collected data were processed in the statistical program SPSS (version 17).

\section{Results and Discussion}

The first objective of this study was set on determining the stress level of employees in public administration. From the results $37.7 \%$ of employees in the Municipality of Shkoder result in high levels of stress at work, while $62.3 \%$ of employees have low levels of stress. (See table 1)

So, we have dominance in quantitative terms of the employees who experience low levels of stress, however the numerical value of the employees who experience high levels of stress is significant given that more than 1 in 3 people report that they experience high stress levels. This is an important issue that should be considered to explore longer and more specifically in other studies on long-term character.

\begin{tabular}{lllll}
\hline \multicolumn{4}{c}{ Table 1. Level of stress at work } \\
& $\begin{array}{l}\text { Frequenc } \\
\text { y }\end{array}$ & Percent & $\begin{array}{l}\text { Valid } \\
\text { Percent }\end{array}$ & $\begin{array}{l}\text { Cumulative } \\
\text { Percent }\end{array}$ \\
V Low level stress & 66 & 62.3 & 62.3 & 62.3 \\
$\begin{array}{l}\text { High level stress } \\
\text { Total }\end{array}$ & 40 & 37.7 & 37.7 & 100.0 \\
\hline
\end{tabular}

The second objective of the study was to determine the factors (stressors) that affect the level of stress. Based on the survey results, overload at work, career development, deadlines, interpersonal relationships and conflict of roles were stressors that affect stress at work. (See table 2). Career development and work overload are two factors which contribute more to the level of stress at work, where their average is respectively 23, 94 and 21, 58 for career development and to work overload. While work under load has smaller impact on stress levels. (Average $=7.41$ and standard deviation $=0.97$ 


\begin{tabular}{llll}
\hline \multicolumn{3}{c}{ Table 2 . Descriptive statistic for factors influencing stress level. } \\
& Mean & $\begin{array}{l}\text { Std. } \\
\text { Deviation }\end{array}$ & $\mathrm{N}$ \\
& 1.38 & 0.487 & 106 \\
Stress & 21.5849 & 1.93646 & 106 \\
Work overload & 23.9434 & 1.76651 & 106 \\
Career development & 17.9811 & 1.40055 & 106 \\
Timelines & 7.4151 & 0.97461 & 106 \\
Work under load & 15.3679 & 1.13243 & 106 \\
Interpersonal relationships & 19.9245 & 1.55960 & 106 \\
Conflict of roles & &
\end{tabular}

Table 3: Pearson correlation matrix between the stress level and work stressors

\begin{tabular}{|c|c|c|c|c|c|c|c|}
\hline & $\begin{array}{l}\text { Stre } \\
\text { ss }\end{array}$ & $\begin{array}{c}\text { Work } \\
\text { overlo } \\
\text { ad }\end{array}$ & $\begin{array}{l}\text { Career } \\
\text { develo } \\
\text { pment }\end{array}$ & $\begin{array}{l}\text { Timelin } \\
\text { es }\end{array}$ & $\begin{array}{c}\text { Work } \\
\text { under } \\
\text { load }\end{array}$ & $\begin{array}{l}\text { Interper } \\
\text { sonal } \\
\text { relation } \\
\text { ships }\end{array}$ & $\begin{array}{l}\text { Confli } \\
\text { ct of } \\
\text { roles }\end{array}$ \\
\hline $\begin{array}{l}\text { Pearson } \\
\text { Correlati } \\
\text { on }\end{array}$ & 1 & $\begin{array}{c}0.753^{*} \\
*\end{array}$ & $\begin{array}{c}0.379^{*} \\
*\end{array}$ & $0.611^{* *}$ & -.012 & $0.575^{* *}$ & ${ }_{*}^{0.690^{*}}$ \\
\hline $\begin{array}{l}\text { Sig.(2- } \\
\text { tailed) }\end{array}$ & & .000. & .000 & .000 & .902 & .000 & .000 \\
\hline $\mathrm{N}$ & 106 & 106 & 106 & 106 & 106 & 106 & 106 \\
\hline
\end{tabular}

Based on these data and according to statistical analysis by Pearson correlation were able to verify the hypothesis of the study which was that 'Between the stress level and work stressors there is positively correlation except, work under load factor that has negative correlation. (See table 3)

But, on the other hand workload or unequal division of tasks ways causes considerable stress to administration employees. So, lack of duties at work would be seen as a relief for public administration employees. On the other hand, and career development is a significant stressor impact on the level of stress at work. Assertions such as 'popularity and politics seem to have important than a job well done', 'Do not you understand how your performance is assessed' are statements which are valued highly on the impact of stress level. So, we can assume that the policy and performance assessment are unclear for employees who see career development a form of popularity.

\section{Conclusion and Recommendations}

Public administration should help its employees to manage stress more effectively. This can be achieved through special training programs on the topics which have individual and organizational stress. This training program can be accomplished by internal assessment or external who are specialized in the field of organizational psychology. The training program can be developed in several stages that could begin with the recognition by participants of the basic concepts of stress, stress management programs work and how to understand the sources of stress if the employee is an individual or organization. The next stage should provide employees how to face stressful situations. Application of Role-Play would be 
advisable in this type of training as will enable participants how to apply the knowledge gained, in order to struggle their occupational stressors.

\section{References}

1) Borman.W (2003) et al. Handbook of Industrial and Organizational Psychology. John Wiley \& Sons.

2) McLean, A. A. (1979). Work Stress. Reading, MA: Addison-Wesley

3) Muchinsky.P (2003) Psychology Applied to Work. Wadswor

4) Kanner, A. D., Coyne, J. C., Schaefer, C., \& Lazarus, R. S. (1981). Comparison of two modes of stress measurement: Daily hassles and uplifts versus major life events. Journal of Behavioral Medicine, 4(1), 1-39. doi:10.1007/BF00844845

5) Sauner, The (2008). How to work without stress. Toena, Tirana.

6) Jerald Greenberg, Robert A. Baron. Behaviour in Organization. Pearson Prentice Hall, 1996

7) Wagner. (1999). Health and Well-Being in the Workplace: A review and synthesis on the literature. Journal of Management. 